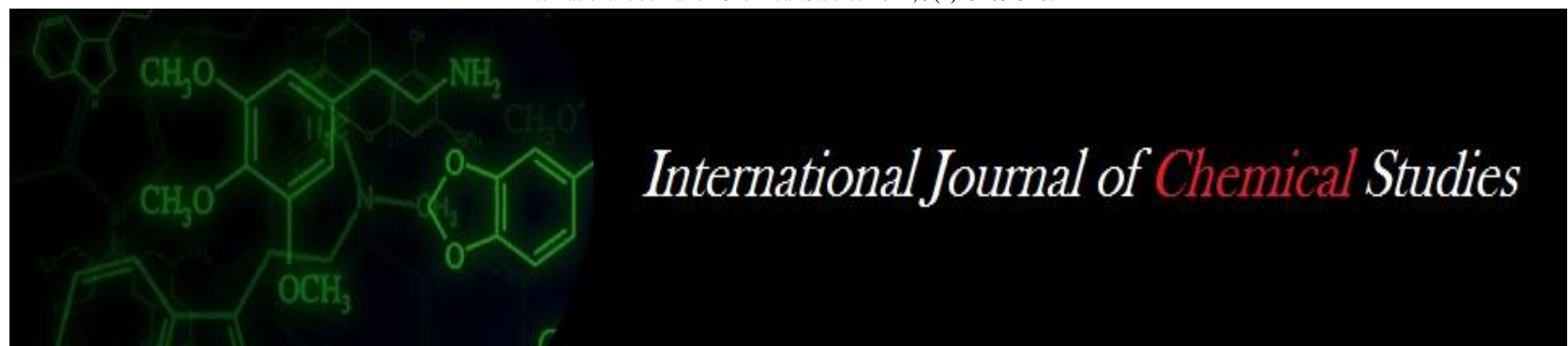

P-ISSN: 2349-8528

E-ISSN: 2321-4902

www.chemijournal.com

IJCS 2021; 9(1): 3165-3167

(C) 2021 IJCS

Received: 04-10-2020

Accepted: 13-12-2020

Tensirani Pradhan

Department of Plant Pathology,

OUAT, Bhubaneswar, Odisha,

India

\section{MK Mishra}

Department of Plant Pathology, OUAT, Bhubaneswar, Odisha,

India

Sandhyarani Nanda

Department of Plant Pathology, OUAT, Bhubaneswar, Odisha, India

\section{Anamita Sen}

Department of Plant Pathology, OUAT, Bhubaneswar, Odisha, India

Corresponding Author: Tensirani Pradhan Department of Plant Pathology, OUAT, Bhubaneswar, Odisha, India

\section{Physiological and nutritional variability of different Pyricularia grisea isolates isolated from various hosts inciting blast disease of rice}

\author{
Tensirani Pradhan, MK Mishra, Sandhyarani Nanda and Anamita Sen
}

DOI: https://doi.org/10.22271/chemi.2021.v9.i1ar.11716

\begin{abstract}
Different isolates of Pyricularia grisea from rice (RPg), Panicum grass (PPg) and finger millet (FPg) were isolated for variability study of the pathogen. Pyricularia grisea was grown on nine different solid media viz., Potato dextrose agar, Potato sucrose agar, Czapek's dox agar, Sabouraud agar, Richard's medium, Potato carrot agar, Panicum leaf extract agar, Rice leaf extract agar and Oat meal agar to study the cultural characteristics of the pathogen. Oat meal agar supported maximum radial growth $(83.33 \mathrm{~mm})$ followed by Potato dextrose agar $(70.17 \mathrm{~mm})$ and Potato carrot agar $(66.17 \mathrm{~mm})$ in case of rice blast. In case of $P$. grisea from Panicum and finger millet, PDA supported highest radial growth of $84.00 \mathrm{~mm}$ and $82.50 \mathrm{~mm}$ respectively followed by Potato sucrose agar $(83.33 \mathrm{~mm}$ and $80.33 \mathrm{~mm})$ respectively. Highest radial growth of the pathogen $(70.13 \mathrm{~mm})$ was found at $30{ }^{\circ} \mathrm{C}$ followed by $25{ }^{\circ} \mathrm{C}(61.88 \mathrm{~mm})$. Sodium nitrate produced highest growth of mycelial dry weight $(12079.0 \mathrm{mg})$ followed by ammonium oxalate (4971.0 mg).
\end{abstract}

Keywords: Pyricularia grisea, rice blast, physiological and nutritional variability

\section{Introduction}

Rice (Oryza sativa L.) is considered as staple food and mainstay for the human beings for their food security. Genus Oryza has 24 different species out of which only two species have been cultivated for staple food, i.e Oryza sativa and Oryza glaberrima and rest 22 species are wild types. Oryza sativa is grown all over the world while Oryza glaberrima has been cultivated in West Africa. Rice is cultivated in 114 countries across the world. The global annual production of rice has been estimated at 697.22 million tons with productivity of 4.4 tons ha ${ }^{-1}$ cultivated in 158.43 million ha.

The potential yield of rice is affected by many diseases caused by fungi, bacteria, viruses, phytoplasma, nematodes and other non-parasitic disorders. Among the fungal diseases, rice blast caused by Pyricularia grisea is considered as a major threat to rice production because of its wide spread distribution and its destructiveness under favourable conditions. The fungus Pyricularia grisea attacks at all stages of the crop and symptoms appear on the following parts of the rice plant: leaf (leaf blast), leaf collar (collar blast), panicle neck node (neck rot) and panicle (panicle blast). The symptoms are more severe in case of neck blast that is characterized by the infection at the panicle base followed by rotting.

\section{Materials and Methods}

Collection of disease samples from different hosts

Blast infected rice leaves were collected from different fields of OUAT farm during the month of October and November 2018. Finger millet leaves infected with blast were collected from MULLaRP, CPR (Centre for Pulses Research) Station, Berhampur, OUAT. Infected Panicum grasses were also collected from farm bonds of OUAT. All the samples collected carefully in polythene bags separately and brought to the laboratory for further study.

\section{Isolation of Pyricularia isolates from different hosts}

The necrotic patches on the diseased leaves of rice, Panicum repens and finger millet were cut into small pieces having both healthy and diseased portion. 
These pieces were surface sterilized by dipping in $0.1 \%$ mercuric chloride solution for 40 seconds and then washed three times with sterilized water. The cut pieces were then transferred to a sterilized petri dish containing oat meal agar medium. Four pieces were inoculated at the four corners of the plates. These plates were then incubated at $27 \pm 1{ }^{\circ} \mathrm{C}$ for the development of fungal growth.

After seven days of incubation mycelial growth of the fungus was seen on the plates. Hyphal tip of the fungus from the mycelial colony was transferred into the petriplates with the help of inoculation needle. This hyphal tip method was subsequently followed two to three times to get pure culture of the pathogen. Pure culture of the fungus was transferred to the oat meal agar slants from the petriplate in aseptic condition. These slants were incubated at room temperature for the growth of the fungus and then stored in refrigerator for future study and use.

\section{Study of cultural characteristics of different Pyricularia gresea isolates}

Cultural characteristics of Pyricularia grisea were studied on nine solid media viz., Potato dextrose agar, Potato sucrose agar, Czapek's dox agar, Sabouraud agar, Richard's medium, Potato carrot agar, Panicum leaf extract agar, Rice leaf extract agar and Oat meal agar. About $20 \mathrm{ml}$ of each media was poured into sterilized petridish and solidified in laminar airflow chamber. Fungal disc of the pathogen $(8 \mathrm{~mm})$ was inoculated at the centre of the media from an actively growing culture plate. These plates were replicated thrice and incubated at $25 \pm 1{ }^{0} \mathrm{C}$. When the maximum growth of the fungus was obtained in any one of the media, the radial growth of the colony was measured. The colony diameter was measured and recorded in the table.

\section{Effect of temperature}

The effect of different temperatures on the growth of Pyricularia grisea isolate from rice was studied at six temperature levels viz., 10, 15, 20, 25, 30 and $35^{\circ}$ C. $20 \mathrm{ml}$ of potato dextrose agar medium was poured into a sterilized petri plate and solidified at room temperature under laminar air flow chamber. Mycelial disc of Pyricularia was inoculated at the centre of the plate from actively growing culture plate and incubated at different temperature levels in a BOD incubator. Each treatment was replicated four times. The mycelial growth in each treatment was recorded at 7 days after inoculation and presented in the table.

\section{Nitrogen utilization}

For nitrogen requirement study, Czapek's dox broth was taken as base media. Different nitrogen sources viz. ammonium carbonate, ammonium oxalate, sodium nitrate, potassium nitrate, sodium nitrite, calcium nitrate were used for the study. In every treatment only the source of nitrogen was changed instead of the original one. The quantity of nitrogen compound was determined on the basis of their molecular weight so as to provide an equivalent amount of nitrogen as that of sodium nitrate present in the base medium. Each treatment was replicated four times. Conical flasks containing different sources of nitrogen were inoculated with the pathogen under aseptic conditions and incubated at $25 \pm 1$ ${ }^{0} \mathrm{C}$. After 15 days, dry mycelial weight of the pathogen was recorded and data was analyzed statistically.

\section{Results and Discussion \\ Growth behavior of Pyricularia grisea isolates in different growth media}

All the three Pyricularia grisea isolates were grown in nine different media. The growth of Pyricularia grisea from rice was highest $(83.33 \mathrm{~mm})$ in oat meal agar followed by potato dextrose agar $(70.17 \mathrm{~mm})$ [Table-1]. Lowest growth was found in Richard's agar medium $(10.00 \mathrm{~mm})$. PDA supported highest radial growth $(84.00 \mathrm{~mm})$ for Pyricularia isolate from Panicum repens and finger millet $(82.50 \mathrm{~mm})$. Mijan Hossain (2000) ${ }^{[4]}$ reported PDA medium with highest radial growth $(85.00 \mathrm{~mm})$ followed by host extract $(80.33 \mathrm{~mm})$ for blast pathogen. Ravindramalviya (2014) ${ }^{[7]}$ also reported highest growth of Pyricularia grisea in PDA followed by Richard's agar medium. In the present study, good growth of rice blast and finger millet blast were found in PDA medium which supported the studies conducted by above scientists. Sporulation of Pyricularia grisea was very sparse in PDA which confirmed the finding of Ravindramalviya (2014) ${ }^{[7]}$. Kulmitra et al. (2017) ${ }^{[3]}$ also found oat meal agar medium to be the best for growth of Pyricularia grisea from rice.

\section{Growth of Pyricularia grisea isolate from rice in different temperature ranges}

Out of six temperature ranges taken for the growth of Pyricularia grisea isolated from rice, $30{ }^{\circ} \mathrm{C}$ was found to be the most conducive for growth with radial growth of 70.13 $\mathrm{mm}$ followed by growth in $25{ }^{\circ} \mathrm{C}(61.88 \mathrm{~mm})$ [Table-2]. Teng (1994) ${ }^{[8]}$ and Arunkumar and Singh (1995) ${ }^{[1]}$ also found 25$30{ }^{0} \mathrm{C}$ to be the optimum for growth of Pyricularia grisea from rice. In the current study the growth increased from 10 ${ }^{0} \mathrm{C}$ upto $30{ }^{\circ} \mathrm{C}$ but then it was decreased at $35{ }^{\circ} \mathrm{C}(20.75 \mathrm{~mm}$ radial growth). This suggested that the growth of the test fungus was retarded at higher temperature. Rajput et al. (2017) ${ }^{[6]}$ also observed good growth and sporulation upto temperature of $27^{\circ} \mathrm{C}$ and decreased growth thereafter upto $32^{\circ} \mathrm{C}$.

\section{Growth of Pyricularia grisea isolate from rice in different nitrogen sources}

Six nitrogen sources were tested to study the growth of Pyricularia grisea isolated from rice. Sodium nitrate was found to be the most effective source and produced highest growth of mycelial dry weight $(12079.0 \mathrm{mg})$ followed by ammonium oxalate $(4971.0 \mathrm{mg})$. Sodium nitrite supported lowest growth of rice blast pathogen $(1324.0 \mathrm{mg})$. Mijan Hossain (2000) ${ }^{[4]}$; Gashaw et al. (2014) ${ }^{[2]}$ and Pandey (2014) [5] also reported sodium nitrate to be the best source of nitrogen for the growth of Pyricularia grisea. The current study confirmed to their findings. The test fungus produced less mycelial dry weight when sodium nitrite $(1324.0 \mathrm{mg})$ and potassium nitrate $(1820.0 \mathrm{mg})$ were taken as nitrogen source even lower than without any nitrogen source i.e. control $(2150.0 \mathrm{mg}$ ). This suggested that sodium nitrite and potassium nitrate could not supply nitrogen rather inhibited the growth of test fungus [Table-3].

Table 1: Growth of Pyricularia grisea isolates in different growth media

\begin{tabular}{|c|c|c|c|}
\hline \multirow{2}{*}{ Treatments } & \multicolumn{3}{|c|}{ Radial growth of the Pyricularia grisea isolates (mm) } \\
\cline { 2 - 4 } & RPg** PPg & FPg \\
\hline $\mathrm{T}_{1} *$ & 70.17 & 84.00 & 82.50 \\
\hline $\mathrm{T}_{2}$ & 54.00 & 83.33 & 80.33 \\
\hline
\end{tabular}




\begin{tabular}{|c|c|c|c|}
\hline $\mathrm{T}_{3}$ & 50.17 & 80.33 & 61.17 \\
\hline $\mathrm{T}_{4}$ & 38.83 & 82.00 & 71.33 \\
\hline $\mathrm{T}_{5}$ & 10.00 & 80.00 & 54.00 \\
\hline $\mathrm{T}_{6}$ & 66.17 & 70.33 & 54.33 \\
\hline $\mathrm{T}_{7}$ & 54.17 & 81.50 & 57.50 \\
\hline $\mathrm{T}_{8}$ & 61.83 & 81.00 & 55.83 \\
\hline $\mathrm{T}_{9}$ & 83.33 & 75.33 & 55.00 \\
\hline $\operatorname{SEm}( \pm)$ & 0.55 & 0.55 & 0.67 \\
\hline $\mathrm{CD}(5 \%)$ & 1.64 & 1.64 & 2.01 \\
\hline
\end{tabular}

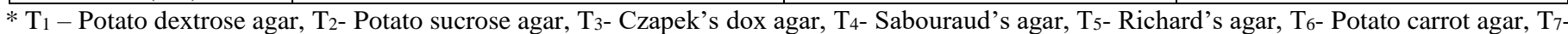
Panicum leaf extract, T8- Rice leaf extract, T9- Oat meal agar

** RPg - Pyricularia grisea from Rice, PPg - Pyricularia grisea from Panicum repens, FPg - Pyricularia grisea from Finger millet.

Table 2: Effect of temperature on growth of Pyricularia grisea isolate from rice

\begin{tabular}{|c|c|}
\hline Temperature & Radial growth of pathogen (mm) \\
\hline $10^{\circ} \mathrm{C}$ & 22.13 \\
\hline $15^{0} \mathrm{C}$ & 36.88 \\
\hline $20^{\circ} \mathrm{C}$ & 46.63 \\
\hline $25^{\circ} \mathrm{C}$ & 61.88 \\
\hline $30^{0} \mathrm{C}$ & 70.13 \\
\hline $35^{\circ} \mathrm{C}$ & 20.75 \\
\hline $\mathrm{SEm}( \pm)$ & 0.47 \\
\hline $\mathrm{CD}(5 \%)$ & 1.40 \\
\hline
\end{tabular}

Table 3: Growth of Pyricularia grisea isolate from rice in different nitrogen sources

\begin{tabular}{|c|c|c|}
\hline Treatments & Nitrogen sources & $\begin{array}{c}\text { Mycelial dry weight of } \\
\text { pathogen (mg) }\end{array}$ \\
\hline $\mathrm{T}_{1}$ & Ammonium carbonate & 2685.0 \\
\hline $\mathrm{T}_{2}$ & Sodium nitrate & 12079.0 \\
\hline $\mathrm{T}_{3}$ & Potassium nitrate & 1820.0 \\
\hline $\mathrm{T}_{4}$ & Ammonium oxalate & 4971.0 \\
\hline $\mathrm{T}_{5}$ & Calcium nitrate & 2395.0 \\
\hline $\mathrm{T}_{6}$ & Sodium nitrite & 1324.0 \\
\hline $\mathrm{T}_{0}$ & Control (No Nitrogen) & 2150.0 \\
\hline $\mathrm{SEm}( \pm)$ & & 75.33 \\
\hline $\mathrm{CD}(5 \%)$ & & 230.71 \\
\hline
\end{tabular}

\section{References}

1. Arunkumar H, Singh RA. Differential response of Pyricularia grisea isolates from rice, finger millet and pearl millet to media, temperature, $\mathrm{pH}$ and light, Indian Journal of Mycology and Plant pathology 1995;25:238242.

2. Gashaw G, Alemu T, Tesfaye K. Morphological, physiological and biochemical studies on Pyricularia grisea isolates causing blast disease on finger millet in Ethiopia, Journal of Applied Biosciences 2014;74:60596071.

3. Kulmitra AK, Sahu N, Sahu MK, Kumar R, Kushram T, Sanath Kumar VB. Growth of Rice Blast Fungus Pyricularia oryzae (Cav.) on Different Solid and Liquid Media, International Journal of Current Microbiology and Applied Sciences 2017;6(6):1154-1160.

4. Mijan Hossain MD. Studies on Blast disease of rice caused by Pyricularia grisea (Cooke) Sacc. In upland areas. M.Sc. Thesis, University of Agricultural Sciences, Dharwad 2000, 52-53.

5. Pandey S. In vitro studies of various culture media, $\mathrm{pH}$, carbon and nitrogen sources on growth of Magnaporthe oryzae causing rice blast, Indian Journal of Tropical Biodiversity 2014;22(2):194-198.

6. Rajput LS, Sharma T, Madhusudhan P, Sinha P. Effect of Temperature on Growth and Sporulation of Rice Leaf Blast Pathogen Magnaporthe oryzae, International
Journal of Current Microbiology and Applied Sciences 2017;6(3):394-401.

7. Ravindramalviya. Studies on integrated approaches for the management of leaf blast of rice caused by Pyricularia grisea (Cooke) Sacc. M.Sc. Thesis, Department of Plant Pathology College of Agriculture, Rewa (M.P.) Jawaharlal Nehru Krishi Vishwa Vidyalaya, Jabalpur, Madhya Pradesh 2014.

8. Teng PS. The epidemiological basis for blast management, CAB International, Wallingford, UK 1994. 